\title{
POTICANJE KREATIVNIH SPOSOBNOSTI UČENIKA GLAZBENIH ŠKOLA
}

\author{
Blaženka Bačlija Sušić1 ${ }^{\text {, Radojka Sućeska Ligutić }}{ }^{2}$ \\ ${ }^{1}$ Učiteljski fakultet Sveučilišta u Zagrebu, Hrvatska \\ blazenkabs@gmail.com \\ ${ }^{2}$ GU Elly Bašić, Zagreb \\ suceskaradojka@gmail.com
}

Primljeno: 28. 7. 2017.

\begin{abstract}
U radu se želi ukazati na važnost poticanja kreativnosti učenika u glazbenoj naobrazbi. Sobzirom na to da prijedlog Nacionalnog kurikuluma za umjetničko obrazovanje nije zaživio u odgojno-obrazovnoj praksi, pozornost je usmjerena na postojeće nastavne planove i programe za osnovne glazbene škole i osnovne plesne škole (2006), i to osobito na plan i program za osnovnu školu Funkcionalne muzičke pedagogije. $\mathrm{Na}$ temelju triangulacije, putem anketnih upitnika te polustrukturiranog intervjua, istraženo je na koji se način u nastavnoj praksi glazbene škole koja radi prema programu Funkcionalne muzičke pedagogije primjenjuju kreativni oblici i metode rada kojima se potiče kreativnost i inovativnost učenika. Dobiveni rezultati ukazuju da ispitani nastavnici imaju visoko razvijenu svijest o značaju kreativnosti za djetetov cjeloviti razvoj te potiču učenike na samostalno rješavanje određenih problema u nastavi. Koriste različite načine za poticanje kreativnosti, pri čemu se improvizacija kao metodički postupak više koristi na nastavi solfeggia nego instrumenta.
\end{abstract}

Ključne riječi: Funkcionalna muzička pedagogija, glazbena naobrazba, kreativni oblici i metode rada, kreativnost, nastavnici

\section{Uvod}

Španjolsko-američki esejist, pjesnik i romanopisac George Santayana (1863-1952) isticao je da su oni koji se ne mogu sjetiti prošlosti osuđeni da ju ponove. Uvriježeno je mišljenje da je povijest učiteljica 
života te da se povijest ponavlja. Ipak, povjesničari se s time ne slažu te smatraju da ne postoje dva identična trenutka, odnosno situacije u povijesti.

Tako je donekle i u povijesti glazbe, odnosno povijesti glazbene pedagogije. Dok se nekada u doba baroka više cijenila improvizacija nego izvođenje pisane literature, početak tiskanja glazbenog djela doveo je do promjene njegova shvaćanja općenito. Nakon Beethovena djelo i skladba postaju nepromjenjivi i nedodirljivi, a stvaralačke aktivnosti putem improvizacije zadržale su se samo u orguljskoj tradiciji te u glazbeno-pedagoškoj praksi gdje im se s vremenom pridavalo sve manje pažnje.

Značaj improvizacije kao glazbeno-stvaralačke aktivnosti i temeljnoga metodičkog postupka u glazbenom obrazovanju ponovno su prepoznali te isticali autori glazbeno-pedagoških pravaca s kraja 19. i početka 20. stoljeća poput Orffa, Kodálya, Jacquesa-Dalcroza, hrvatske glazbene pedagoginje Elly Bašić i dr. Zanimljivo je da je još u 18. stoljeću Jean-Jacques Rousseau (1712-1778), predstavnik razdoblja prosvjetiteljstva, kao veliki ljubitelj glazbe shvaćao važnost stvaralačkih aktivnosti te je stoga naglašavao da nije dovoljno da djeca samo pjevaju pjesme nego ih trebaju i stvarati jer se jedino na taj način može steći pravo znanje glazbe (Begbie, 2013).

Upravo je stvaralačka sloboda nužan element stvaralaštva i kreativnosti. Novija istraživanja pokazuju da su nadzor, procjenjivanje, pretjerana kontrola i kruti rokovi četiri čimbenika koji najčešće smanjuju kreativnost ljudi (Goleman 2000). Stvaralaštvo i kreativnost postali su danas imperativ suvremenog društva. Uz znanje, traže se i kreativnost, originalnost, ideje. Naš sustav obrazovanja još uvijek ne prepoznaje dovoljno ove vrijednosti te malo pažnje posvećuje razvoju djetetove kreativnosti. Kreativnost podrazumijeva upotrebu divergentnog mišljenja te pronalaženje novih i originalnih ideja te odgovora na isto pitanje ili problem. Ona je inherentni potencijal svakog djeteta, koji je važno poticati od djetetove rane dobi.

Dok je kreativno mišljenje često konceptualno povezano s izvođačkom i vizualnom umjetnošću, glazbeni pedagozi tradicionalno naglašavaju vještine čitanja notnog teksta i izvođenja glazbe (Swanwick, 1988). Glazbeno obrazovanje često se više fokusira na konvergentne vještine kao što su, primjerice, pjevanje i glazbena pismenost, nego na divergentne vještine, poput komponiranja i improviziranja (Fairfield, 
2010). Isto tako, Campbell (1991), Kratus (2007) i Hargreaves (1999) smatraju da je dominantna tradicija zapadnog glazbenog obrazovanja na svim razinama usmjerena na reproduktivne glazbene vještine kao što su čitanje notnog teksta i razvoj tehničkih izvođačkih vještina u kojima dominira pristup usmjeren na nastavnika. Rezultati istraživanja Fung (1997) i Koutsoupidou i Hargreaves (2009) također su pokazali da glazbeni programi koji se temelje na istraživanju zvuka i improvizaciji doprinose poboljšanju sposobnosti djetetova kreativnog razmišljanja u glazbenoj naobrazbi. Brown (2008) ističe da putem kreativnog mišljenja nastavnici mogu dovesti učenike do dubljeg razumijevanje glazbe, dopuštajući pritom učenicima stvaranje novih skladbi i bavljenje improvizacijom, u okruženju usmjerenom na učenika.

Webster (2002) smatra da, za razliku od glazbene reprodukcije, kreativno mišljenje i sam stvaralački proces trebaju biti u središtu profesionalnih aktivnosti suvremenih glazbenih pedagoga. Uz razvoj solističkog i skupnog oblika izvođenja, sveobuhvatniji pristup glazbenoj naobrazbi podrazumijeva i učenje kompozicije, improvizacije, slušanje glazbe, kulturni kontekst i povezanost s drugim umjetnostima. Stoga isti autor smatra da će razdoblje s kraja 20. stoljeća i početka novog milenija u budućoj povijesti glazbenog obrazovanja biti navedeno kao kritična točka u povijesti ove profesije. Ističe da glazbeni pedagog više ne može očekivati uspjeh u podučavanju glazbe usmjerenošću na reproduktivne aktivnosti, odnosno podučavajući učenike na koji način reproducirati tuđa glazbena djela prema njegovim uputama. Pažnju je potrebno usmjeriti i razvoju estetskog izričaja i glazbene, stvaralačke slobode učenika.

Autori Azzara (1993) i Swanwick i Franca (1999) smatraju da djeca koja sudjeluju u aktivnostima koja zahtijevaju kreativno mišljenje posjeduju višu razinu glazbenog postignuća. Nadalje, Csikszentmihalyi (1996) navodi da takva djeca pokazuju i povećanu razinu motivacije te posjeduju bolju konceptualizaciju elemenata poput melodije, harmonije, ritma i glazbenih oblika (Swanwick i Franca, 1999). Reimer (2003) naglašava da glazbeno stvaranje uključuje kreativnost u skladanju, izvedbi, improvizaciji i slušanju, dok Fairfield (2010) pod kreativnim mišljenjem u učenju glazbe podrazumijeva učenikovo sudjelovanje u komponiranju, aranžiranju, improviziranju i koreografiranju glazbe. Stoga, glazbeni pedagozi pozivaju nastavnike glazbe da se obrazuju u vještinama koje uključuju kreativno mišljenje kao što su skladanje 
(Kratus, 2012; Odena i Welch, 2007, 2012) i improviziranje (Wright i Kanellopoulos, 2010; Bernhard, 2013).

\section{Kreativnost i stvaralaštvo kao imperativ suvremene odgojno-obrazovne prakse}

U suvremenoj se nastavi kreativnost smatra bitnom odrednicom koja pridonosi mijenjanju tradicionalne i reproduktivnom znanju usmjerene nastave $\mathrm{u}$ humanističku, stvaralačku i otvorenu zajednicu (Koludrović, 2009). Poticanje i razvoj učenikove kreativnosti ističe se kao jedan od temeljnih odgojno-obrazovnih ciljeva aktualnog $\mathrm{Na}$ cionalnog okvirnog kurikuluma za predškolski odgoj i obrazovanje te opće obvezno i srednjoškolsko obrazovanje (MZOS, 2011). U cilju daljnjeg unapređenja obrazovnog sustava, na temelju članka 81. Ustava Republike Hrvatske, Hrvatski sabor je na sjednici 17. listopada 2014. usvojio Strategiju obrazovanja, znanosti i tehnologije čijom je objavom u Narodnim novinama započela njezina provedba (NN 124/2014). Prihvaćanjem ovog dokumenta potvrđeno je da Hrvatska prepoznaje obrazovanje i znanost kao svoje razvojne prioritete te je spremna na prilagodbe u cilju daljnjeg dugoročnog razvoja. U svrhu daljnjeg, što boljeg informiranja javnosti o glavnim ciljevima strategije te poticanja njezine provedbe, osmišljen je projekt Nove boje znanja, Strategija obrazovanja znanosti i tehnologije (2014) koji ujedno predstavlja njezin jedinstveni vizualni identitet. Strategija obrazovanja, znanosti $i$ tehnologije koja je, među ostalim, usmjerena k obrazovanju koje aktivno potiče cjelovit individualni razvoj svakog učenika, promiče društvenu jednakost i demokratske vrijednosti te snažno pridonosi društvenome i gospodarskome razvoju. Prema navedenom dokumentu, sustav obrazovanja treba omogućiti svim učenicima stjecanje znanja, vještina i vrijednosti potrebnih za uspješan život u suvremenom društvu tako što će ih osposobiti za cjeloživotno učenje i rad te omogućiti da se razvijaju kao kreativni, aktivni i samopouzdani pojedinci odgovorni za osobni i društveni razvoj (Nove boje znanja. Strategija obrazovanja znanosti i tehnologije, 2014).

Kao jedna od vrijednosti ističe se »razvoj osobnih kreativnih potencijala i njihovo korištenje za vlastitu dobrobit i dobrobit društva $\mathrm{u}$ cjelini« (Nove boje znanja, 2014, 42). Uz inovaciju i usklađivanje postojećih dokumenata u području ranog i predškolskog, osnovnoškol- 
skog i srednjoškolskog odgoja i obrazovanja, kao jedan od pod-ciljeva koji se odnosi na sve razine i vrste odgoja i obrazovanja po prvi se puta navodi izrada Nacionalnog kurikuluma za umjetnički odgoj i obrazovanje (Nove boje znanja, 2014). Na taj bi način nacionalni kurikulum za umjetničko obrazovanje predstavljao dio cjelovita projekta sa svojim specifičnim ciljevima i mjerama koje se tiču umjetničkog obrazovanja. S obzirom na to da je Kurikularna reforma u cijelosti obustavljena, doneseni Prijedlog nacionalnog kurikuluma za umjetničko obrazovanje (Cjelovita kurikularna reforma. Rani predškolski, osnovnoškolski i srednjoškolski odgoj i obrazovanje, 2016) nije prihvaćen, pa samim time nije niti zaživio u odgojno-obrazovnoj praksi.

Stoga smo se, u želji da istaknemo važnost poticanja kreativnosti učenika u glazbenoj naobrazbi, usredotočili na postojeće dokumente kojima je regulirano umjetničko odnosno glazbeno obrazovanje u Hrvatskoj, Nastavne planove i programe za osnovne glazbene i plesne škole (NN 102/2006). U okviru navedenog dokumenta kao jedan od temeljnih ciljeva Nastavnog plana i programa za osnovnu glazbenu školu navodi se da je

»... cilj glazbenoga odgojno-obrazovnog sustava da odgojem i obrazovanjem profesionalnih glazbenika različitih profila i zanimanja stalno proizvodi onaj dio društvene nadgradnje koji je obuhvaćen pojmom glazbene umjetnosti.« (NN 102/2006, 2)

Nasuprot navedenom cilju, Nastavni plan i program za osnovnu školu Funkcionalne muzičke pedagogije kao jedan od temeljnih ciljeva ističe:

»... razvijanje urođenih djetetovih biopsihofizioloških datosti glazbom; stjecanje znanja i ovladavanje vještinama i umijećima potrebnim za izvođenje, stvaranje i razumijevanje glazbe; očuvanje i poticanje dječje mašte i razvoj kreativnosti (...) izgrađivanje svestrane, slobodne, kreativne, humane, senzibilne osobnosti svakog pojedinca bez obzira na buduće profesionalno opredjeljenje.«(NN 102/2006, 135)

\section{Funkcionalna muzička pedagogija Elly Bašić}

Značaj kreativnosti u glazbenoj naobrazbi u Hrvatskoj osobito je isticala glazbena pedagoginja Elly Bašić u svojem glazbeno-pedagoškom konceptu Funkcionalne muzičke pedagogije (FMP). Još kao studentica na Muzičkoj akademiji u Zagrebu osnovala je 1929. godine 
svoju privatnu glazbenu školu Beethoven u želji da potakne jedan drugačiji pristup glazbenoj naobrazbi. Njezin entuzijazam nije zamro ni zabranom rada ove privatne škole 1945. godine. Tako je, ustrajući u svojoj ideji nakon prihvaćanja Elaborata Funkcionalne muzičke škole (Bašić, 1962, u: Lovričević, 2005) od tadašnjih vlasti, 1963. godine započela s radom Funkcionalna muzička škola kao područni odjel pri OŠ Gračani u Zagrebu. Dobivši svoj vlastiti prostor u Mlinarskoj ulici u Zagrebu, 1965. godine zaživjela je Centralna funkcionalna muzička škola koja i danas djeluje na istoj adresi te nosi ime njezine utemeljiteljice - Glazbeno učilište Elly Bašić.

Tuksar (1992) navodi da je glazbeno-pedagoški koncept FMP usmjeren djetetovoj prirodnoj dispoziciji mašte te problematici njezina poticanja, oslobađanja i očuvanja tijekom djetetova razvoja u odraslog te glazbenoj kulturi i socijalizaciji djeteta kroz glazbu. Isti autor ističe da je Elly Bašić dugi niz godina proučavala kreativnost i spontanost djeteta te radila na istraživanju Kreativnost djeteta kao prirodna datost $i$ mogućnost održavanja i razvijanja kreativnosti u omladini i odraslima. Njezina temeljena istraživačka preokupacija je bila

»... zašto kako opća tako i umjetnička pedagogija ne uspijeva očuvati u svakom djetetu, kasnijem svakom čovjeku taj prirodni interes za umjetnost?« (Bašić, 1987, 204)

»Otkrivamo (...) da je necenzurirano, spontano, motoričko i sinkretičko izražavanje još uvijek prisutno u 'svakom' odraslom (...) Samo treba da mu oljuštimo odgojem i 'obrazovanjem' nataložene dogmatske slojeve.« (Bašić, 1987, 204)

Bašić (1971) ističe da djetetovu stvaralačku maštu najviše ugrožavaju institucionalizirane strukture kao što su školstvo, školski programi, udžbenici i priručnici, kao i pedagoški i didaktički postupci. Tvrdila je da na izvorno, čisto dječje glazbeno stvaralaštvo nailazimo tamo gdje se ono osjeća bez kontrole odraslih, dok se s druge strane neadekvatnim odgojnim vođenjem djeteta kroz njegovo djetinjstvo koči njegova stvaralačka sposobnost. Svojom idejom glazbenog odgoja pokušala je pronaći izravniji put kojim dijete usvaja umjetničku zakonitost na primjeren način, adekvatan njegovim urođenim sposobnostima, njegovom psihičkom razvoju i dobi, gdje će učeći umjetnost, čak i kroz igru, od prvog dana razviti u prvom redu svoju umjetničku senzibilnost (Bašić, 1957). Polazila je od stajališta da je djecu važno učiti rješavanju problema, pri čemu je glazba jedno od temeljnih sredstava u potica- 
nju i razvoju djetetove mašte i kreativnosti. Upravo stoga smatrala je da svako dijete ima pravo na glazbenu naobrazbu, da svako dijete ima sluha i ritma, a zadatak glazbenog pedagoga je da ih razvija ne u cilju stvaranja budućih glazbenika, nego cjelovite ličnosti budućeg odraslog. Kao temeljne metodičke postupke isticala je improvizaciju, učenje kroz igru i doživljaj, naglašavajući pritom važnost samog stvaralačkog procesa, a ne rezultata. Glazbena se improvizacija tako kao konstitutivni element nastave FMP kroz osmišljen i planski vođen program provodi od najranije dobi - glazbenog vrtića, i nadalje tijekom cijele vertikale školovanja u različitim nastavnim područjima (instrumentalna nastava, solfeggio, polifonija i dr.) (Perak Lovričević, 2005).

\section{Istraživanje}

\section{Cilj i problemi}

Temeljni cilj istraživanja bio je ispitati kakva su stajališta nastavnika Glazbenog učilišta Elly Bašić (GU) iz Zagreba koji rade prema programu FMP s obzirom na pojedine aspekte kreativnosti i načina njezina poticanja kod učenika.

Sukladno navedenom cilju, postavljeni su sljedeći problemi istraživanja kojima smo željeli utvrditi:

- kakvo je stajalište nastavnika koji rade prema programu FMP spram kreativnosti općenito,

- kakvo je stajalište nastavnika koji rade prema programu FMP o njihovoj ulozi/doprinosu u poticanju kreativnosti učenika,

- kakvo je stajalište nastavnika koji rade prema programu FMP o povezanosti između kreativnosti i muzikalnosti učenika,

- kakvo je stajalište nastavnika koji rade prema programu FMP s obzirom na način prepoznavanja te poticanja kreativnosti kod učenika u njihovu glazbeno-pedagoškom radu.

\section{Metoda}

Kao postupke za prikupljanje podataka koristili smo anketiranje te intervjuiranje, a kao instrumente anketni upitnik te polustrukturirani intervju. S obzirom na korištenje različitih izvora podataka u cilju do- 
bivanja što objektivnijih rezultata, rad se temelji na triangulaciji čiji je osnovni smisao da se pojava može točnije uočiti ako ju se promatra s različitih stajališta (Mužić, 2004). U skladu s time, ova metoda podrazumijeva kombinirano korištenje kvalitativnog i kvantitativnog pristupa istraživanju.

U okviru kvalitativne analize kodirali smo dobivene podatke te ih kasnije preveli u kategorije i pretvorili u određeni rezultat. Rezultate iz peterostupanjske skale procjene Likertovog tipa obradili smo na kvantitativni način putem deskriptivne statistike.

\section{Sudionici}

Prigodni uzorak predstavlja 25 nastavnika GU Elly Bašić iz Zagreba (15 nastavnika instrumenta i 10 nastavnika solfeggia), a istraživanje je provedeno u 12. mjesecu 2016. godine.

\section{Instrument i postupak ispitivanja}

Anketni se upitnik sastojao od 12 čestica, pri čemu se pet čestica temeljilo na ljestvici procjene u okviru koje je korištena peterostupanjska skala Likertovog tipa. Vrijednost jedan (1) na skali označavala je pritom »uopće se ne slažem《, dok je vrijednost pet (5) značila »u potpunosti se slažem«. Sedam pitanja bilo je otvorenog tipa, što predstavlja osobito značajan izvor podataka koji, kao što ističu Cohen, Manion i Morrison (2007), daju iskren i osoban odgovor pa se u njima mogu naći »biseri informacija koje inače upitnikom ne bismo mogli dobiti« (Cohen, Manion i Morrison 2007, 255). Kako bismo dodatno utvrdili stajališta i mišljenja nastavnika, proveli smo polustrukturirani intervju s nastavnicima.

\section{Rezultati istraživanja i interpretacija}

Prvih pet pitanja upitnika vezana su uz stajališta ispitanika o kreativnosti koja su izrazili odgovorima na Likertovoj skali procjene. Dobiveni rezultati ukazuju da se najveći broj ispitanika, njih 17, u potpunosti slaže s tvrdnjom da je kreativnost odlika svakog djeteta, pet ispitanika se slaže s tvrdnjom, dok se dvoje ispitanika donekle slaže s navedenom tvrdnjom. Prema dobivenim rezultatima svi ispitanici su 
pozitivno odgovorili na navedenu tvrdnju (ocjenama od tri do pet) što je u skladu s jednom od temeljnih postavki FMP koja ističe da je svako dijete kreativno (Perak Lovričević, 2005). Razvijenu svijest ispitanika o značajnoj ulozi kreativnosti u njihovu osobnom i društvenom razvoju potvrđuju dobiveni odgovori na drugu tvrdnju upitnika. Tako se 23 ispitanika u potpunosti slaže s tvrdnjom koja ističe značaj kreativnosti u čovjekovom cjelokupnom razvoju. U skladu s time navedeni su i odgovori ispitanika na treću tvrdnju prema kojima 22 ispitanika navodi da im je kreativnost bitna u životu. Upravo je razvijena svijest nastavnika o značajnoj ulozi kreativnosti u čovjekovom razvoju temeljni preduvjet njezina poticanja u njihovu kako pedagoškom tako i glazbeno-pedagoškom radu. Robinson (2015) potiskivanje djetetova kreativnog potencijala pripisuje formalnom školovanju. Uz to, ističe da taj proces zapravo počinje puno ranije budući da ni odgojitelji nisu dobro obučeni u umjetničkim znanjima i nemaju razvijenu svijest o važnosti njegovanja djetetove mašte. Garvis i Pendergast (2011) smatraju da je važno utjecati na razvoj njihove svijesti, s obzirom na to da uvjerenja odgojitelja o vlastitoj samoefikasnosti u podučavanju utječu na oblikovanje njihovih kompetencija u odgojno-obrazovnoj praksi.

Navedeno stajalište dodatno potvrđuju i rezultati sljedeće dvije tvrdnje koji ukazuju da 23 ispitanika smatra važnim poticati kreativnost učenika, pri čemu njih 20 smatra da nastavnik može utjecati na poticanje ili gušenje kreativnosti učenika. Od istih stajališta polazila je i Elly Bašić u svome radu:

»Predispozicije svakog prosječnog djeteta daju muzičkom odgoju mnoge mogućnosti. Ovisi od onih kojima je povjeren odgoj djeteta - od roditelja, odgojitelja, učitelja, nastavnika u općeobrazovnim školama i pedagoga umjetničkih škola - koliko će od tog bogatstva dječjih dispozicija ili sposobnosti vrijeme i odgoj ugušiti - ili razviti.« (Bašić, 1957, u: Letica, 2014, 38)

To nadalje potvrđuju i provedena istraživanja (Nabishah, et al., 2009; Abrandt Dahlgren, et al., 2006) kojima je zaključeno da nastavnikova otvorenost za nova i drukčija rješenja te fleksibilnost u strukturiranju nastave pospješuju proces učenja i potiču stvaranje ugodne klime.

U prvom pitanju otvorenog tipa ispitanici su trebali navesti u kojim se aktivnostima smatraju kreativnima, pri čemu je naznačeno da nije važno da su za tu aktivnost dobili priznanje. Neki su ispitanici naveli više aktivnosti u kojima sebe smatraju kreativnima. Tako najveći broj ispitanika (12) smatra sebe kreativnima u podučavanju glazbe te u 
pripremanju hrane (uglavnom u kuhanju, pečenju kolača), dok se isti broj ispitanika smatra kreativnim u podučavanju općenito. Samo četiri ispitanika sebe smatra kreativnim u sviranju, što možemo protumačiti činjenicom da se radi o nastavnicima glazbe koji svoj kreativni potencijal više izražavaju u svom pedagoškom radu, a manje u aktivnom nastupanju i koncertnoj karijeri. Abramo i Reynolds (2015) razlikuju kreativnosti u podučavanju i glazbenu kreativnost, pri čemu navode da kreativni pedagozi ne podučavaju nužno »kreativno mišljenje« i možda niti sami nisu kreativni u glazbi, ali primjenjuju kreativni pristup i tako oplemenjuju svoju obrazovnu praksu. Nadalje, tri ispitanika sebe smatra kreativnima u uređenju doma, vrta i organizaciji prostora, dok po dva ispitanika sebe vide kreativnima u drugim umjetničkim područjima poput slikanja, likovnog izražavanja i plesa, u odgoju i radu s djecom te pri kombiniranju boja i odijevanju. Po jedan ispitanik sebe smatra kreativnim pri komponiranju i aranžiranju, vođenju ansambla, režiranju i snimanju, u igri, u provođenju slobodnog vremena te tulumarenju. Prema navedenim rezultatima, ispitanici se smatraju kreativnima te svoj kreativni potencijal iskazuju u različitim područjima. Odena (2001) navodi da nastavnici imaju svoja osobna gledišta o kreativnosti koja imaju utjecaj na njihov pedagoški pristup i ocjenu aktivnosti koje uključuju kreativni proces. Bašić (1973) smatra da je stvaralaštvo jedno općeljudsko svojstvo pri čemu je važno da se kod djeteta spriječi njegovo gašenje i degeneracija kako se kasnije kod odraslih ne bi moralo »mučno« oslobađati ono što je u njima kao djeci blokirano.

Odgovore na pitanje kako bi definirali svoj posao, odnosno što smatraju svojom misijom te ciljem kojemu kontinuirano teže, grupirali smo u tri kategorije: opći i glazbeni odgoj te razvoj djeteta, poticanje ljubavi prema glazbi i doživljaju ljepote glazbe te poticanje interesa i uživanja u glazbi. Pri tome 22 ispitanika svojim poslom, odnosno životnom misijom smatraju opći i glazbeni odgoj te razvoj djeteta, 11 ispitanika svoje odgovore vezuje uz isticanje ljubavi i doživljaja ljepote glazbe, dok šest ispitanika navodi želju za poticanjem interesa i uživanja u glazbi među svojim učenicima. U kategoriju opći i glazbeni odgoj te razvoj djeteta svrstali smo odgovore koji su usmjereni djetetovu cjelovitu razvoju, razvoju njegovih sposobnosti, kreativnosti, socijalnih, umjetničkih i glazbenih potencijala, osjećaja odgovornosti i radnih navika te konkretnosti i točnosti, oblikovanju glazbenog ukusa, osamostaljenju, oslobađanju i poticanju samopouzdanja i dr. Upravo je 
razvoj djetetove cjelovite ličnosti jedan od temeljnih ciljeva FMP koji ističe Elly Bašić:

»Ne želimo kod djeteta izdvojiti izvjesne osobine (sluh), već odgojiti cjelovitu ličnost u njemu.«(Bašić, 1976, 7)

U kategoriju ljubav i doživljaj ljepote glazbe svrstali smo sljedeće odgovore ispitanika vezane uz njihovu misiju te cilj kojemu kontinuirano teže: prenijeti djeci ljubav prema glazbi, upoznati ih s ljepotom glazbe te osvijestiti njezin značaj i ljepotu. Uz to izražavaju želju da učenici ponesu sa sobom lijepu uspomenu na glazbenu školu i sl. U treću kategoriju svrstali smo odgovore kojima ispitanici kao svoju misiju ističu poticanje djetetova interesa i uživanja u glazbi kao primjerice: podijeliti s učenicima radoznalost za istraživanje, postići da dijete uživa u glazbi i sl.

Na pitanje vezano uz naporne radne dane u smislu velikog broja sati, tražilo se od nastavnika da navedu što je to što ih inspirira da unatoč naporu rade bolje. Dobivene odgovore svrstali smo u sedam kategorija, pri čemu najveći broj ispitanika (devet) ukazuje da ispitanici svoju inspiraciju pripisuju samim učenicima i njihovoj osobnosti (njihova individualnost, njihov pogled i osmjeh, vedrina, znatiželja, spontanost i originalnost, muzikalnost, entuzijazam, duhovitost, motiviranost, pozitivan kontakt i energija te zajednička interakcija u postizanju novih spoznaja i stvaranju glazbe, učenici koji »grizu« i sl.), interakciji s učenicima (osam) (pozitivan kontakt, zajedničko sviranje i sl.), odgovornosti prema poslu (sedam) te ljubavi prema djeci i glazbi samoj po sebi (pet) (osmjeh svakog djeteta, pogledi učenika, raznolikost glazbenog repertoara, dobar zvuk lijepe melodije, ozbiljniji program koji svira učenik srednje škole i sl.). To ukazuje da ispitane nastavnike FMP u radu pokreću te inspiriraju na rad sama djeca, interakcija s njima te ljubav prema djeci, ali istovremeno i odgovornost prema svom poslu. Upravo bi ljubav prema djeci trebala biti temelj bilo kojeg oblika pedagoškog i odgojiteljskog poziva. Ladson-Billings (2009) navode da većina osnovnoškolskih nastavnika najčešće kao razlog za odabir pedagoškog poziva navodi ljubav prema djeci. Pritom Darder (2002) smatra da ukoliko nastavnici ne uspijevaju svjesno promišljati svoju nastavnu praksu i odnos sa svojim učenicima utoliko neće uspjeti prepoznati njihove predrasude i pristranosti koje mogu usmjeravati ili ograničavati njihovu međusobnu interakciju. Kao čimbenike koji doprinose njihovoj ustrajnosti u radu unatoč napornim radnim danima u smislu velikog broja sati, sedam ispitanika ističe odgovornost prema svom poslu (ozbi- 
ljan odnos prema poslu, osjećaj odgovornosti, očekivanja djeteta i sl.). Uz to, zanimljivo je da neki ispitanici svoju izdržljivost i inspiraciju pripisuju osobnom karakteru i želji za osobnim razvojem (tri), dok isti broj ispitanika kao izvor inspiracije unatoč naporu navodi hranu i piće (kava, sok, čokolada i sl.).

Osma tvrdnja odnosi se na segment, odnosno dio posla koji najviše umara nastavnika u danima kada mu je nastava vremenski duga. Gotovo svi ispitanici (24) odgovorili su da ih osobito umara manjak interesa te nezainteresiranost učenika (uzastopno ponavljanje i uvježbavanje istog problema, zadržavanje njegova interesa i pažnje, poticanje na rad i sl.). Dio ispitanika kao segment posla koji ih osobito umara navode prirodu samoga posla (osam), a koja uključuje: potrebu za neprekidnim govorenjem, pjevanjem, slušanjem (umjesto samostalnim sviranjem), potom predugim sjedenjem, pisanjem dokumentacije, potrebu za međuljudskim kontaktima, osobito s roditeljima i sl. Uz navedene odgovore neke smo čestice svrstali u kategoriju ostalo (tri), pri čemu ispitanici navode da sve ovisi o njihovoj energiji i koncentraciji učenika, nesposobnosti učenika i sl. Dobiveni rezultati istraživanja ukazuju na potrebu poticanja dodatnog interesa učenika stvaralačkim aktivnostima poput improvizacije, slušanja glazbe s učenikom i sl., koje navodi Webster (2002) ističući pritom da se nastava glazbe više ne smije temeljiti samo na reprodukciji. Upravo takve mogućnosti pruža program FMP koji uz improvizaciju kao metodički postupak pruža mogućnost pohađanja tzv. A (usmjerenog) i B (šireg) programa. U prvi plan stavlja se odgoj djetetove cjelokupne i svestrane ličnosti (Perak Lovričević, 2005) pri čemu se u sklopu navedenog B programa dodatno potiče i razvoj djetetove kulturne svijesti (odlasci na koncerte, slušanje glazbe, sviranje popularnih melodija na nastavi instrumenta i sl.). Takav program namijenjen je prvenstveno djeci koja se ne namjeravaju profesionalno baviti glazbom, odnosno djeci koja zbog svojih sposobnosti ili interesa ne mogu ili ne žele nastaviti glazbeno obrazovanje u srednjoj školi.

Deseto pitanje odnosilo se na vezu između muzikalnosti i kreativnosti. Najveći broj ispitanika (18) smatra da su muzikalna djeca uglavnom i vrlo kreativna te da je muzikalnost dio kreativnosti, pri čemu jedno pokreće drugo. Tako primjerice jedan ispitanik navodi: »Je li moguće biti muzikalan, a ne i kreativan? Muzikalnost je specifična kreativnost. « Dio ispitanika (pet) navodi da muzikalnost i kreativnost nisu nužno povezani te da kreativnost ne podrazumijeva i muzikalnost. 
Ispitanici dakle smatraju da kreativno dijete nije nužno i muzikalno, odnosno da ako netko nema razvijenu muzikalnost ne znači da nije kreativan. Dva ispitanika smatraju da muzikalnost i kreativnost nisu povezani. Kao što je navedeno, Elly Bašić polazila je od stajališta da je svako dijete kreativno. Uz to je isticala da su mnoga djeca koja pjevaju »falš« izuzetno muzikalna, pri čemu je muzikalnost smatrala jednom kompleksnom komponentom koja ima više glazbenopsihološko određenje (Bašić, 1969).

U odgovorima na pitanje koji su znakovi učenikove kreativnosti te po čemu prepoznaju muzikalnost i kreativnost učenika, u skladu s odgovorom na prethodno pitanje većina ispitanika povezuje muzikalnost i kreativnost učenika. S obzirom na veliki broj različitih odgovora, ove odgovore svrstali smo u dvije kategorije koje se odnose na reakcije učenika po kojima ispitanici prepoznaju učenikovu muzikalnost $i$ kreativnost te na stvaralačke aktivnosti.

Od ukupnog broja odgovora, 25 ispitanika kao znakove prepoznavanja učenikove kreativnosti i muzikalnosti ističe učenikove reakcije na satu. Pri tome se najveći dio odgovora (pet) odnosi na osjetljivost na dinamičke i agogičke nijanse te na zvukovnu različitost, na fraziranje, smisleno izvođenje notnog teksta te na učenikovu emotivnu reakciju, ritmično i točno sviranje (tri), na pokrete tijekom sviranja, na učenikovu lakoću izvođenja i reakcije na ono što nastavnik traži, na shvaćanje prenesenog značenja i spontanu izražajnost u sviranju, reakcije učenika na sviranje drugih (dva) i na fućkanje, ritmiziranje rukama i nogama te glazbeni doživljaj (dva).

Istraživačke i stvaralačke aktivnosti kojima ispitanici izražavaju načine prepoznavanja učenikove kreativnosti i muzikalnosti predstavljaju drugu kategoriju u koju smo svrstali odgovore ispitanika (17). Pri tome se najveći dio odgovora odnosi na nove ideje i rješenja učenika o tome kako nešto treba zvučati (pet), na eksperimentiranje na vlastitu instrumentu, samostalno osmišljavanje vlastite glazbe (četiri) te na spontanu improvizaciju (tri), dok se ostatak odgovora odnosi na igranje glazbenim idejama i pokušaj sviranja poznate melodije na instrumentu. Iz navedenih rezultata vidljivo je da postoje brojni pokazatelji kreativnosti i muzikalnosti učenika koje nastavnici GU Elly Bašić prepoznaju i potiču kod učenika. Kao poželjni kriterij za ocjenu učenikove kreativnosti Fryer (1996) upravo ističe originalnost i maštovitost učenika. Isticanjem učenikovih kvaliteta i vrijednosti utječe se na samopouzda- 
nje učenika što nadalje utječe na njegovu motivaciju i interes u radu. Asmus (1986) tvrdi da nastavnik koji pažljivo organizira nastavu tako da svi učenici postignu određenu razinu glazbene izvedbe, utječe na razvoj pozitivne samopercepcije učenika i njegova samopouzdanja, odnosno samosvijesti o njegovim glazbenim sposobnostima.

Osobito inspirativnim i zanimljivim nalazimo odgovore na 12. pitanje u kojem ispitanici navode na koje sve načine potiču kreativnost svojih učenika. S obzirom na izuzetno veliki broj odgovora i njihovu raznolikost, odgovore smo grupirali u veći broj kategorija. Ispitanici su najveći broj odgovora (11) pripisali korištenju asocijacija i priča kao načina poticanja kreativnosti kod učenika. Dio odgovora ispitanika (osam) vezano je uz poticanje učenika na samostalno donošenje vlastitih ideja i odluka (poticanje učenika na samostalno rješavanje određenih problema te na samostalno odlučivanje kako će oblikovati dinamiku, tempo, karakter kompozicije, kako će riješiti tehnički problem, prstomet i sl.). Upravo je jedan od elemenata kreativnog mišljenja na koji se najčešće nailazi u psihološkoj i glazbeno-pedagoškoj literaturi, rješavanje problema i njegova uloga u kreativnom razmišljanju pojedinca (Webster, 1992). Elly Bašić je isticala da je »stvaralaštvo produktivni rad, dok je djetetov razvoj danas još uvijek usmjeren na reproduktivnost, na znanje činjenica, a ne na rješavanje problema« (Bašić, 1973, 63). Na pokazani interes nastavnika za učenika te njegovu osobnu kreativnost odnosi se sedam odgovora, dok šest odgovora ukazuje da ispitani nastavnici kreativnost učenika potiču na sinkretski cjelovit način (pokret, ples, likovni, literarni izraz, priča i sl.). Bašić (1986) je u svojem glazbeno-pedagoškom konceptu isticala važnost djetetova sinkretskog izraza, pri čemu je sinkretizam definirala kao »jedinstvenost nastajanja muzikalnih, govornih i motoričkih elemenata u cjelovitom muzikalnom izražavanju spontanog djeteta« (Bašić, 1986, 17). Bez obzira na to što improvizacija predstavlja jedan od temeljnih metodičkih postupaka u nastavi FMP-a, samo pet ispitanika (nastavnika instrumenta) improvizaciju definira kao sredstvo poticanja učenikove kreativnosti, dok svi ispitani nastavnici teorijskih predmeta i solfeggia (10) smatraju improvizaciju sredstvom za poticanje učenikove kreativnosti. To ukazuje na činjenicu da ispitani nastavnici instrumenta imaju razvijenu svijest o značaju poticanja kreativnosti učenika, ali više koriste druge načine poticanja kreativnosti svojih učenika u odnosu na improvizaciju. Koutsoupidou i Hargreaves (2009) istražili su razliku između šestogodišnjaka koji su u svojoj glazbenoj izobrazbi imali prilike za improvizaciju i onih čija nastava to 
nije dozvoljavala. Rezultati istraživanja pokazali su da improvizacijske aktivnosti imaju veći utjecaj na razvoj kreativnosti nego didaktičko podučavanje. Ovi rezultati upućuju na to da glazbene aktivnosti trebaju ostaviti prostora za improvizaciju u cilju razvoja kreativnosti.

Kao način poticanja kreativnosti učenika, četiri ispitanika navodi stvaranje ugodnog ozračja te raspoloženje nastavnika, dok zajedničko sviranje i slušanje drugih, oslobađanje učenika straha od pogreške te odabir programa u dogovoru s učenikom ističe tri ispitanika. Upravo je stvaranje ugodne klime u razredu Asmus (1986) u svojem istraživanju motivacije za postignućem istaknuo kao jedinstveni čimbenik za glazbeno obrazovanje. Dva ispitanika kao poticaj koristi mogućnost sviranja drugih instrumenata, dok sviranje učenika u neobičnom položaju te korištenje različitih sredstava poput loptica, marama, spužvica i sl., navodi po jedan ispitanik.

\section{Rezultati polustrukturiranog intervjua s nastavnicima}

U cilju prikupljanja dodatnih informacija o stajalištima ispitanika spram kreativnosti te načinima njezina poticanja u glazbeno-pedagoškoj praksi, kao dodatni izvor podataka koristili smo postupak intervjuiranja. Intervjuirano je osam nastavnika, $i$ to četiri nastavnika solfeggia i četiri nastavnika instrumenta. Radi fleksibilnosti samog načina prikupljanja podataka odabrana je metoda polustrukturiranog intervjua koja se s jedne strane temelji na zadanoj strukturi pitanja koja će biti postavljena svim sudionicima istraživanja, a s druge strane dozvoljava kreiranje i postavljanje novih pitanja koja nastaju kao rezultat sadržaja koji sugovornik iznosi (Gillham, 2005). Putem polustrukturiranog intervjua koji se sastojao od pet pitanja otvorenog tipa željeli smo dobiti jedinstvene, osobne informacije od ispitanika. Ispitanicima smo postavili sljedeća pitanja: Recite nam što mislite o glazbenoj naobrazbi i poticanju kreativnosti učenika?; Što za Vas predstavlja spontana improvizacija?; Kakva je po Vama uloga priče u poticanju učenikove kreativnosti?; Ako ju koristite u nastavi, molimo Vas da opišete na koji način; Navedite načine na koje potičete učenike na rješavanje određenih problema s kojima se susreću pri interpretaciji; Što mislite o poticanju učenikove kreativnosti i sviranju klasičnog programa?

Zaključeno je da se premalo vremena posvećuje poticanju učenikove kreativnosti kroz spontanu improvizaciju u nastavi instrumenta. 
Većina ispitanih nastavnika instrumenta zbog opsežnog gradiva ne želi žrtvovati vrijeme za spontanu improvizaciju jer se boje da neće stići završiti potrebno gradivo. Nisu svjesni dobrobiti stvaralačkih aktivnosti za dijete koje se jednoga dana mogu odraziti u nekim drugim životnim područjima te doprinijeti razvoju njegova samopouzdanja.

Iz dobivenih odgovora ispitanika zaključeno je da se spontana improvizacija u nastavi FMP više provodi na nastavi solfeggia nego instrumenta. U instrumentalnoj nastavi obično se koristi u početnoj nastavi ili s učenicima koji imaju poteškoća u svladavanju zadanog programa. Dok neki nastavnici instrumenta neprovođenje improvizacije pripisuju nedostatku vremena, neke, bez obzira na njihov interes, sputava priroda samog instrumenta (primjerice puhačkog) s obzirom na način dobivanja tona. Ipak, iskazuju interes i želju za osobnim istraživanjem te dodatnim usavršavanjem svojih znanja u ovom području. Neki smatraju da je osobnost i kreativnost samog nastavnika značajan čimbenik u poticanju kreativnosti te da i sami učenici često potiču i inspiriraju nastavnika. Spontanu improvizaciju povezuju s doživljajem zvuka, istraživanjem zvuka, s igrom i pričom kojom se učenik uvodi u temu improvizacije i stvara određeno ozračje. Veći broj ispitanika općenito navodi korištenje priče u svom radu s učenicima, i to primjerice pri rješavanju nekog problema, kao motivacijsko sredstvo, za dočaravanje ugođaja pjesmice koju dijete svira i sl. Ispitani nastavnici instrumenta ponovno navode nedostatak vremena za improviziranje i pričanje priča.

Nastavnici potiču učenike na samostalno rješavanje određenog problema, potiču ih da sami dođu do zaključka, da razmišljaju, otkrivaju i samostalno zaključuju pri rješavanju prstometa, dinamike, tehničkih problema, znaka za početak pri sviranju učenika s korepetitorom i sl. Kreativnost se može postići samo kad učenik dobro vlada kompozicijom koju izvodi i kad se opusti. Kreativnost u sviranju klasičnog programa, uz priče i asocijacije, nastavnici potiču i sviranjem poznatih melodija ili filmske glazbe koja ih oslobađa i potiče njihovu spontanost koja se potom posredno odražava i na izvođenje zadanog programa. Sloboda i kolege (1996) pri proučavanju odnosa između neformalnog vježbanja i izvođačkog postignuća zaključili su da studenti s najslabijim rezultatima posvećuju najmanje vremena neformalnom vježbanju u smislu sviranja omiljenih pjesama radi osobnog užitka, glazbenog "zezanja« s prijateljima i sl. Zaključili su da upravo takav oblik neformalnog vježbanja predstavlja motivacijski poticaj za učenikovu posvećenost vježbanju i glazbenom angažmanu. Uz to, Renwick i McPherson 
(2002) smatraju da učenici vježbaju drugačije kada sviraju komade koji im se sviđaju. Uz navedeno, neki ispitanici smatraju da pojedini stilovi i skladatelji, kao primjerice Bach, ipak ograničavaju učenikovu slobodu, pa je tako i »igranje« s dinamikom ograničeno stilskim obilježjima. Jedan ispitanik pritom smatra da se na taj način potiče disciplina, a kreativnost upravo dolazi putem nje.

\section{Zaključak}

Specifičnost programa FMP koji stavlja naglasak na poticanje djetetove mašte i kreativnosti te uvažava individualni razvoj svakog učenika, uz opušteno ozračje u nastavi kojemu uvelike doprinosi nevrednovanje učenikovih znanja putem ocjena, osnovna su pretpostavka i preduvjet poticanja kreativnosti učenika. Dobiveni rezultati ukazuju da ispitani nastavnici imaju visoko razvijenu svijest o značaju kreativnosti za djetetov cjeloviti razvoj te ju smatraju bitnim čimbenikom osobnog i društvenog razvoja. Smatraju je odlikom svakog djeteta te su svjesni svoje uloge i potrebe za njezinim poticanjem kod djeteta. Kreativnost i muzikalnost svojih učenika prepoznaju po njihovim reakcijama te istraživačkim i stvaralačkim aktivnostima. Kao značajan čimbenik u poticanju kreativnosti učenika navode osobnost i kreativnost samog nastavnika te samih učenika koji isto tako potiču i inspiriraju nastavnika. Uz priče i asocijacije koje ujedno predstavljaju i značajno motivacijsko sredstvo u nastavi, koriste različite načine poticanja učenikove kreativnosti. Potiču učenike na samostalno rješavanje određenog problema, navode ih da sami dođu do zaključka, da razmišljaju, otkrivaju i zaključuju. Više od polovice ispitanih nastavnika svojom misijom, odnosno ciljem kojemu kontinuirano teže u svojem poslu, navode opći i glazbeni odgoj i razvoj djeteta te poticanje ljubavi i doživljaja ljepote glazbe.

Rezultati istraživanja ukazuju da se improvizacija kao temeljni metodički postupak u nastavi FMP više koristi na nastavi solfeggia nego na individualnoj nastavi instrumenta. Ispitani nastavnici instrumenta to pripisuju nedostatku vremena i svojim nedovoljnim kompetencijama za provođenje ove aktivnosti, osobito kod instrumenata kao što su primjerice puhački. Stoga na temelju dobivenih rezultata možemo zaključiti da je uz različite ideje i načine poticanja interesa i kreativnosti učenika FMP-a potrebno više pažnje posvetiti provođenju improvizacije kao temeljnog metodičkog postupka u nastavi instrumenta bez obzira 
na dodatne zahtjeve propisanog programa i u skladu s time nedostatka vremena. Potrebno je dodatno educirati nastavnike instrumenta o načinima i mogućnostima provođenja improvizacije (osobito spontane u početnoj nastavi) bez obzira na prirodu instrumenta. Upravo na to ukazuju i provedena istraživanja Odena i Welch (2012) koja ukazuju da se nastavnici koji imaju iskustva u improviziranju i komponiranju ugodnije osjećaju u ovim aktivnostima, te ujedno ukazuju na potrebu dodatnog obrazovanja ostalih glazbenih pedagoga u vještinama u kojima se koristi kreativno mišljenje kao što su improvizacija (Bernhard, 2013; Wright i Kanellopoulos, 2010) i skladanje (Kratus, 2012; Odena i Welch, 2007; 2012).

Nastavnikov osobni doživljaj i iskustvo u stvaralačkim aktivnostima temeljni je preduvjet razvoja njegove svijesti o njihovu značaju u djetetovom kako glazbenom tako i općem razvoju. Jedino na taj način, putem osobnog iskustva, nastavnik će u svakom djetetu, bez obzira na njegove glazbene predispozicije i znanja, moći potaknuti njegov kreativni glazbeni izraz te doživljaj glazbe. Stoga bi kreativni, odnosno stvaralački izraz i doživljaj djeteta trebao biti izazov ne samo općeg kurikuluma i kurikuluma za umjetničko obrazovanje nego imperativ i cilj kojemu je potrebno težiti za dobrobit cjelokupnog društva.

\section{Literatura}

Abramo, Joseph; Reynolds, Amy (2015), „'Pedagogical creativity' as a framework for music teacher education «, Journal of Music Teacher Education, 25(1), str. 37-51. doi: https://doi.org/10.1177/1057083714543744

Abrandt Dahlgren, Madeleine; Hult, Håkan; Dahlgren, Lars-Ove; Hård af Segerstad, Helene; Johansson, Kristina (2006), »From senior student to novice worker: Learning trajectories in political science, psychology and mechanical engineering «, Studies in Higher Education, 31(5), str. 569-586.

doi: https://doi.org/10.1080/03075070600923400

Asmus, Edward P. (1986), »Student beliefs about the causes of success and failure in music: A study of achievement motivation «, Journal of Research in Music Education, 34, str. 262-278. doi: https://doi.org/10.2307/3345260

Azzara, Cristopher D. (1999), »An aural approach to improvisation«, Music Educators Journal, 86, str. 21-25. doi: https://doi.org/10.2307/3399555

Bašić, Elly (1957), »Muzički izraz djeteta. Crtež kao odraz doživljaja muzike«, Bilten zavoda unapređenje nastave i općeg obrazovanja NR Hrvatske, Zagreb, str. 39-50. 
Bašić, Elly (1971), »Zadaci i perspektive u istraživanju dječjeg stvaralaštva«, Umjetnost $i$ dijete, 14, str. 11-19.

Bašić, Elly (1973), »Improvizacija kao kreativni čin«, Umjetnost $i$ dijete, 26, str. 44-69.

Bašić, Elly (1976), Sedam nota sto divota, Zagreb: Školska knjiga.

Bašić, Elly (1986), »Sinkretizam u muzikalnom izražavanju djeteta«, Tonovi, Zagreb, 1, str. 17-23.

Bašić, Elly (1987), »Muzikalna potka u likovnom i govornom izražavanju spontanog djeteta«, u: Kroflin, Livija; Nola, Danica; Posilović, Antonija; Supek, Rudi (ur.), Dijete i kreativnost, Zagreb: Globus, str. 161-209.

Begbie, Jeremy (2013), Music, Modernity and God. Essays in Listening, Oxford: Oxford University Press. doi: https://doi.org/10.1111/ijst.12199

Bernhard, Christian (2013), »Music education majors' confidence in teaching improvisation«, Journal of Music Teacher Education, 22, str. 65-72. doi: https://doi.org/10.1177/1057083712458593

Brown, Julie, K. (2008), »Student-centered instruction: involving students in their own education«, Music Educators Journal, 94(5), str. 30-38. doi: https://doi.org/10.1177/00274321080940050108

Campbell, Patricia Shehan (1991), »Unveiling the mysteries of musical spontaneity«, Music Educators Journal, 78(4), str. 21-24.

doi: https://doi.org/10.2307/3398332

Louis, Cohen; Lawrence, Manion; Ketih, Morrison (2007), Metode istraživanja u obrazovanju, Naklada Slap: Jastrebarsko.

Csikszentmihalyi, Maihaly (1996), Creativity: Flow and the Psychology of Discovery and Invention, New York: Harper Collins.

Darder, Antonia (2002), Reinventing Paulo Freire: A Pedagogy of Love, Boulder, Co: Westview Press.

Fairfield, Sara Mae (2010), Creative Thinking in Elementary General Music: A Survey of Teachers' Perceptions and Practices. Doktorska disertacija. Iowa Research Online. Dostupno na: http://ir.uiowa.edu/etd/798

Fryer, Marilyn (1996), Creative Teaching and Learning, London: Paul Chapman Publishing.

Fung, V. (1997), »Effect of a sound exploration program on children's creativity in music«, Research Studies in Music Education, 9(1), str. 13-19.

doi: https://doi.org/10.1016/j.sbspro.2012.06.107

Gillham, Bill (2005), Research Interviewing: The Range of Techniques, Holstein: Open University Press.

Goleman, Daniel (2000), »Leadership that gets results«, Harvard Business Review, March-April, str.76-91. 
Hargreaves, David (1999), »The knowledge-creating school«, British Journal of Educational Studies, 47(2), str. 122-144.

doi: https://doi.org/10.1111/1467-8527.00107

Koutsoupidou, Theanož; Hargreaves, David (2009), »An experimental study of the effects of improvisation on the development of children's creative thinking in music «, Psychology of Music, 37(3), str. 251-278.

doi: https://doi.org/10.1177/0305735608097246

Koludrović, Morana (2009), „Pitanja i zadaci u udžbenicima kao elementi poticanja divergentnog mišljenja«, Pedagogijska istraživanja, 6(1-2), str. 179-190.

Kratus, John (2007), »Music education at the tipping point «, Music Educators Journal, 94(2), str. 42-48. doi: https://doi.org/10.1177/002743210709400209

Kratus, John (2012), »Nurturing the songcatchers«, u: Bowman, Wayne D.; Lucia Frega, Ana (ur.), Handbook of Philosophy in Music Education, Oxford: Oxford University Press, str. 367-385.

Ladson-Billings, Gloria (2009), The Dreamkeepers: Successful Teachers of African American Children, San Francisco, CA: Jossey-Bass.

Letica, Marina (2014) (ur.), Vjerujem svakom djetetu - tekstovi iz ostavštine Elly Bašić, Zagreb: GU Elly Bašić.

[MZOS] Ministarstvo znanosti, obrazovanja i sporta RH(2011), Nacionalni okvirni kurikulum za predškolski odgoj i obrazovanje te opće obvezno i srednjoškolsko obrazovanje, Zagreb: Ministarstvo znanosti, obrazovanja i sporta RH.

Nabishah, Mohamad; Farihah, Haji Suhaimi; Srijit, Das; Abdus, Salam; Siti, Mariam Bujang; Mohamad, Arif Kamarudin; Harlina, H Siraj; WN Zurinah (2009), »Problem based learning facilitation: New challenges to higher education Educators«, International Medical Journal, 16(4), str. 243-246.

Nastavni planovi i programi za osnovne glazbene i plesne škole (2006), Narodne novine, 102/2006.

Strategija obrazovanja znanosti i tehnologije (2014), Narodne novine, 124/2014.

Nove boje znanja (2014), Strategija obrazovanja, znanosti i tehnologije. Dostupno na: http://www.novebojeznanja.hr/UserDocsImages/datoteke/KB_web.pdf [20. 11. 2016.].

Odena, Oscar (2001), »Developing a framework for the study of teachers' views of creativity in music education«, Goldsmiths Journal of Education, 4(1), str. $59-67$.

Odena, Oscar; Welch, Graham (2007), »The influence of teachers' backgrounds on their perceptions of musical creativity: A qualitative study with secondary school music teachers«, Research Studies in Music Education, 28(1), str. 71-81. doi: https://doi.org/10.1177/1321103X070280010206 
Odena, Oscar; Welch, G. (2012), »Teachers' perceptions of creativity«, u: Odena, Oscar (ur.), Musical Creativity: Insights from Music Education Research, Series: SEMPRE studies in the psychology of music. Burlington: Ashgate, str. $29-48$.

Perak Lovričević, Nataša (2005) (ur.), Glazbeno učilište Elly Bašić 1965-2005, Zagreb: GU Elly Bašić.

Prijedlog nacionalnog kurikuluma za umjetničko obrazovanje (2016), Cjelovita kurikularna reforma. Rani predškolski, osnovnoškolski i srednjoškolski odgoj i obrazovanje. Dostupno na:

https://esavjetovanja.gov.hr/ECon/MainScreen?entityId=3497 [10. 6. 2017.]

Reimer, Bennett (2003), A Philosophy of Music Education: Advancing the Vision, Upper Saddle River, NJ: Prentice Hall.

Renwick, James M.; McPherson, Gary E. (2002), »Interest and choice: Studentselected repertoire and its effect on practising behaviour «, British Journal of Music Education, 19(2), str. 173-188.

doi: https://doi.org/10.1017/S0265051702000256

Sloboda, John A.; Davidson, Jane W.; Howe, Michael J. A.; Moore, Derek G. (1996), »The role of practice in the development of performing musicians «, British Journal of Psychology, 87, str. 287-309. doi: https://doi.org/10.1111/j.2044-8295.1996.tb02591.x

Swanwick, Keith (1988), Music, Mind, and Education, New Jersey: Routledge.

Swanwick, Keith; Franca, Cecilia (1999), „Composing, performing and audiencelistening as indicators of musical understanding «, electronic version, British Journal of Music Education, 16(1), str. 5-19.

Tuksar, Stanislav (1992), »Elly Bašić - nagrada I. Filipović za životno djelo«, Tonovi, 7(1), str. 49-51.

Webster, Peter (1992), »Research on creative thinking in music: The assessment literature «, u: Colwell, Richard (ur.), Handbook of Research on Music Teaching and Learning, New York: Schirmer Books, str. 266-279.

Webster, Peter R. (2002), »Creative thinking in music: Advancing a model«, u: Timothy, Sullivan; Lee, Willingham (ur.), Creativity and Music Education, Toronto: Canadian Music Educators' Association, str. 16-33.

Wright, Ruth; Kanellopoulos, Panagiotis (2010), »Informal music learning, improvisation and teacher education«, British Journal of Music Education, 27(1), str. 71-87. doi: https://doi.org/10.1017/S0265051709990210 


\section{FOSTERING THE CREATIVE ABILITIES OF MUSIC SCHOOL STUDENTS}

\section{Blaženka Bačlija Sušić, Radojka Sućeska Ligutić}

This paper emphasises the importance of encouraging creativity in music education. Since the proposal of the National Curriculum for Art Education has not yet been implemented in educational practice, the focus of this paper is on existing curriculae for elementary music schools and elementary dance schools (2006), especially on the curriculae for the Functional Music Pedagogy primary school. Based on a triangulation of different methods, through a questionnaire survey and semi-structured interviews, the teaching practice of music schools working under the Functional Music Pedagogy programme was investigated in its application of creative forms and working methods that encourage the creativity and innovation of students. The results obtained indicate that the teachers examined have a highly developed awareness of the importance of creativity, and that they encourage students to independently solve certain problems in the classroom. They use different ways to stimulate creativity, where improvisation is used more often as a basic methodical tool in teaching solfège than in individual instrumental instruction.

Key words: Functional Music Pedagogy, music education, creative forms and methods of work, creativity, teachers 